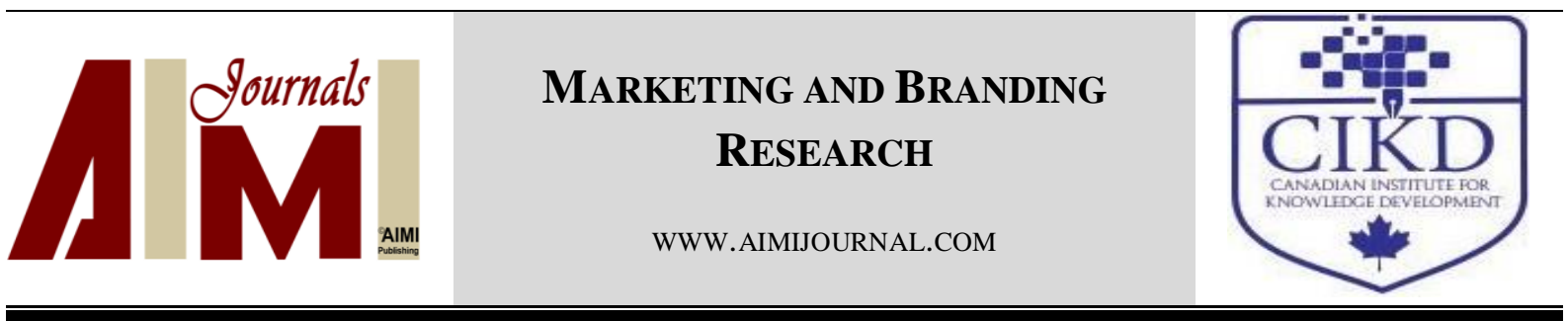

\title{
Comparing the Effective Factors of Traditional Archers' Bow Brand Preferences
}

\author{
Tanyeri Uslu*, Merve Yanar Gürce \\ İstanbul Gedik University İstanbul, 34876 Turkey
}

\begin{tabular}{l}
\hline \\
Keywords: \\
Brand Preference, \\
Traditional Archery, \\
Content Analysis \\
\hline Received \\
28 October 2018 \\
Received in revised form \\
18 December 2018 \\
Accepted \\
18 December 2018 \\
\hline
\end{tabular}

\section{Abstract}

\begin{abstract}
The aim of this study is to compare and determine the effective factors of traditional archers' bow brands preferences from the multicultural perspective. In depth-interviews and focus group studies were conducted with senior and experienced traditional archers from different countries in order to collect the data. Content analysis technique was used to analyze the data and the proposed model was created accordingly. Traditional archers from Turkey and some European countries were participated in this research. According to the results of the analysis; perceived price of brand, customer relationships, product characteristics, and product availability were found as determiners of traditional archers' bow brand preferences.
\end{abstract}

Correspondence:

tanyeriuslu@gmail.com

CAIMI Journals

From ancient times to the use of guns, the bow was a very significant hunting tool and weapon of battle field around the world. It is used by almost all cultures and is often mentioned as one of the most important inventions. The significance of bow and arrow has been subjected to many archery traditions and its practices until today, as well as many written and oral histories, artistic representations, literature, and folklore. Even though the use of bow and arrow for military and hunting activities declined after the invention of guns, archery has remained as a sport in many countries (Grayson, French, \& O'Brien, 2007). Many organizations were established to support archery activities. In the nineteenth and 
twentieth century, the Western traditions of recreational archery were developed to the modern sport of archery (Klopsteg, 2004). It is mainly a competitive sport and recreational activity. Both modern and traditional archery are practiced worldwide today among many countries.

Traditional archery has become widespread today. For the competitions, having a decent bow has gained importance. Therefore, necessity of differentiation and branding has become an obligation for bow makers to survive in this competitive era. According to that, the main purpose of this study is to find out traditional archers' bow brand preferences. The concept of brand loyalty states that a consumer chooses a brand among the other brands and does not replace with another (Kotler \& Keller, 2003). Product image is the component which plays an important role in the brand preference and that image is based on consumer's awareness and the related information about brands (Kwok, Uncles, \& Huang, 2006).

The present study investigates traditional archers' bow brand preference and its effective factors and tries to find answer for the question: "How perceived price of brand, customer relationship management, product characteristics and product availability affect traditional archers' bow brand preferences?" For that purpose, in-depth interviews and focus group studies were conducted with traditional archers in some of the European countries and Turkey.

\section{Literature Review \\ Perceived Price of Brand}

Perceived price can be described as "the customer's judgment about a service's or product's average price in comparison to its competitors" (Chen, Gupta, \& Rom, 1994). The concept of perceived price is based on the nature of the competitive-oriented pricing approach. This approach focuses on customers' concerns about whether they are being charged more than or about the same as charged by competitors. De Ruyter, Bloemer, and Peeters, (1997) found that an increase in service quality levels leads to an increase in satisfaction level, and pointed out that low perceived quality may also result in high service satisfaction. They also stated that customers may not necessarily buy the highest level of quality service. That is, price, convenience, and availability may increase customer satisfaction without actually influencing customer perceptions of service or product quality.

\section{Customer Relationships}

The idea of creating a relationship with customers based on quality, relationship, innovation, and learning is regarded as a more sustainable strategy and can be seen as largely inimitable by competitors in essence, a strategy that could create a long-term competitive advantage (Grönroos, 2000; Payne, 2000). Customer Relationship Management (CRM) has proven to be a critical tool in increasing a firm's profitability by enabling it to identify the best customers and satisfy their needs, in order to make them remain loyal to the firm's activities (Thomas \& Sullivan, 2005). The purpose of CRM implementation is that it should considerably enhance firm performance, a quality of any marketing activity (Krasnikov, Jayachandran, \& Kumar, 2009; Lehmann, 2004; Rust, Lemon, \& Zeithaml, 2004). Therefore, pursuing long-term 
relationships with customers is more profitable for brands (Morgan \& Hunt, 1994; Jayachandran, Sharma, Kaufman, \& Raman, 2005).

\section{Product Characteristics}

The relationship between technical and physiological product characteristics and consumer quality perception has been formalized in Hauser and Clausing's (1993) study, which has the aim of facilitating market-oriented product development. The relationship between physiological product characteristics and consumer quality perception is at the heart of market-oriented product development. In order to design products accepted by consumers, it is necessary to translate consumer demands into product specifications that are actionable from the producer's point of view. A number of studies have found that product variety and uniqueness are two important factors that drive consumers to purchase a certain product (Sim \& Koi, 2002).

\section{Product Availability}

The critical influence of product availability on consumer demand has been analyzed by previous literature (Bronnenberg, Mahajan, \& Vanhonacker, 2000; Bruno \& Vilcassim, 2008; Pancras, 2011). Farris, Olver, and De Kluyver (1989) note that small stores tend to stock only popular or large-market-share brands. Given the limited choice set in such stores, consumers are often willing to compromise their purchase decisions by switching to an available brand (Reibstein \& Farris, 1995).

\section{Method}

The aim of this research is to examine the effective factors of traditional archer's bow brand preferences. In-depth interviews were conducted with ten senior archers from European countries, eighteen experienced archers from Turkey. It is suggested that focus group studies should have at least six participants in one group (Onwuegbuzie \& Leech, 2007). Three focus group studies were also conducted with eighteen experienced archers to compare and determine the effective factors of traditional archers' bow brand preferences. As an important contribution, qualitative research enables to explore the meaning of phenomena and to reach a better and deeper understanding of real-life behavior (Cornish, 2012). Furthermore, indepth interviews enable to scrutinize the subconscious perceptions of respondents. The archers were chosen from different European countries in order to have a various sample for this research. In this study, six archers out of twenty-five are concentrated on horseback archery and rest of them are concentrated on flight shooting archery, target archery, and bowhunting.

The participants were acquainted with the research topic. During in-depth interviews, participants were not directed specifically by researchers to bring out their brand preferences. In-depth interviews lasted approximately one hour for each participant and focus group studies lasted approximately two hours. According to Harris (2001), content analysis method is used to analyze the interviews that identifies the research questions and constructs, examines chosen texts to specify unit of analysis to classify the responds based on their 
themes, and generates coding scheme or coding rules respectively. According to that, the proposed conceptual model of the study is shown in Figure 1 based on the content analyses.

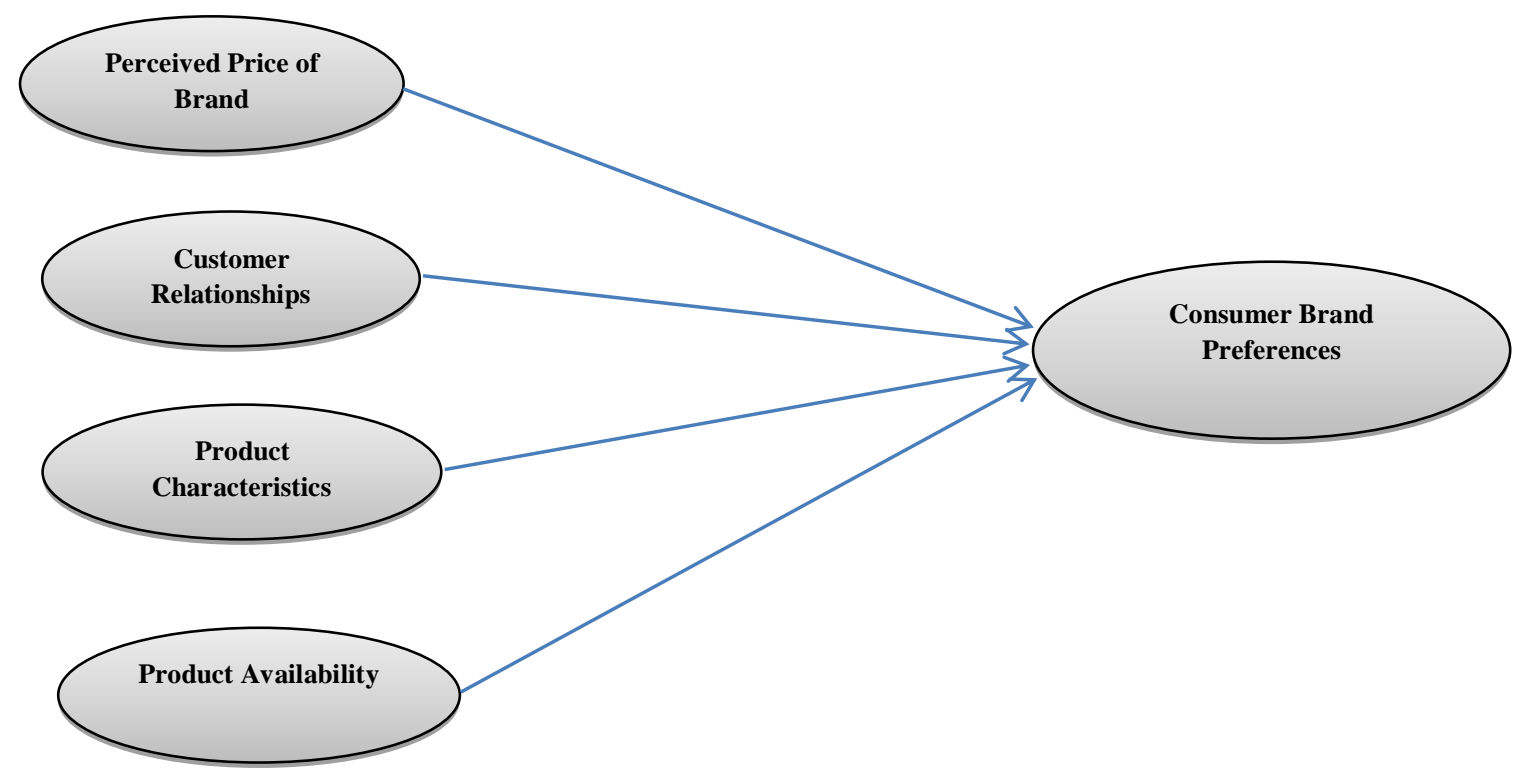

Figure 1. Proposed conceptual model

\section{Results}

According to the results of in-depth interview and focus group studies, the variables of the study were determined as perceived price of brand, customer relationships, product characteristics and product availability. The variables were found according to the content analysis. The purpose of this study is to find out the effective factors of traditional archers' bow brands preferences. In this point, the experience of the archers in related disciplines such as target shooting, flight shooting, horseback archery and bow-hunting has gained importance. In the first place, we asked the participants to answer the questions: "How many years have you been interested in traditional archery", and "Which disciplines are you interested in related to traditional archery?" Experiences of archers' in this study were between five and thirty years. Most of the archers were interested in both target and flight shooting, and the rest were horseback archers or bow-hunters. The other question that was "Do you prefer domestic or foreign brands while purchasing your bow, and which brands are they?" The common response from most of the archers was: "I prefer good bow makers". Another supporting view was "Making a bow is more important than selling one". Similarly, "A bow maker does not only sell the product but also takes his/her bow's responsibility"; "The most important thing when a bow maker sells a bow he/she takes care of his/her customer because having a great support from producers brings customers satisfaction with it". Specifically, Turkish archers' views were "We have mostly preferred foreign bows because of limited domestic product alternatives, but now domestic bows may be more preferable in Turkey compared to four years ago."

The following questions regarding to the archers' bow brand preferences were: "Is there any bow brand and model that you mostly desire to use?", and "Is there any bow brand and 
model that you would never give up?" One of the over-twenty-years experienced horseback archers from Europe says "I have used many different bows until having my own bow type which is Living Arrow Bow". Keskin Bows as a domestic brand and Grózer Bows from Hungary as a foreign brand came in the first place as the most preferred choices of the participants from Turkey. The other recognized bow brands were Şimşek Bows and Yıldırım Bows from Turkey, Mariner Bows and Ali Bows from China, Saluki Bows from the USA, Végh Bows from Hungary, and Sylwester Styrczula Bows from Poland. It was not given a specific bow brand name by European archers they mostly prefer to use. However, two of the experienced archers from Europe stated their preferences as "I prefer Végh's Turkish bow model both for flight shooting and target shooting disciplines"; "I prefer Végh's Turkish bow model for flight shooting and I also prefer Végh's Tatar and Hun bow models for target shooting disciplines. Similarly, one of the Turkish archers stated "I never give up Grózer's Turkish base bow model", and another Turkish archer says, "I never give up Laminated Crimean Tartar Bow of Grózer". Additionally, one of the archers from Turkey described a bow as easy to pull, fast, durable and small sized. Moreover, one archer states "I never give up Grózer's bow because it has longer life; however, I also never give up Keskin Bows because of their good customer relationships". When it was asked for which factors affect archers' bow preferences, the following answers were given by the participants: high service quality, fair pricing, standardization, draw length, draw weight, draw experience, price, material, accessibility, design, durability, performance, and being tested by experts. Finally, participants were asked to reply "What are the services they expect from a bow maker?" According to the answers; quality, customer service, English-speaking customer service representative, no warranty hassles, fair pricing, open info about their products, transparency, customization, sponsorship, and lifelong warranty (that doesn't result from user faults) have found as determinants of the expected services. According to the content analysis, the results of the determinants of brand preferences are shown in Table 1.

Table 1

Content Analysis

\begin{tabular}{ll}
\hline Perceived Price of Brand & Fair pricing, Price Policy \\
Customer Relationships & After Sales Service, Warranty, Customer Service, Transparency, Customization, Sponsorship, Fast reply \\
Pesign, Quality, Authenticity, Standardization, Material, Stability, Performance, Durable, Fast, Strong, \\
Product Characteristics & $\begin{array}{l}\text { Precise, Well balanced, Draw Weight, Draw Length, Weight, Lightness, Speed, Appearance, no hand } \\
\text { shock }\end{array}$ \\
Product Availability & Accessibility \\
\hline
\end{tabular}

\section{Conclusion}

Both European and Turkish archers from different disciplines have commonly given importance to perceived price of brand, customer relationships, product characteristics and product availability. European archers have chance to experience different bow brands and models because they can easily access reasonable priced bows. In addition, European archers reach both domestic and foreign producers easily. 
Another important finding is that it is an obligation for the bow makers to manage customer relations and build strong relations with customers, it thus delivers customer value. This is particularly an important finding because bow makers may embrace value from customers in the form of sales, profits, and customer loyalty for the brand in return. They should also understand the market place and archers' needs. European Bow makers can sell their products by applying fixed exchange rates to certain countries regarding their fluctuations in currency exchange rates. This causes bows to be more accessible for the archers who desire to use their most preferred bows. When we look at the brands that Turkish participants mostly prefer to use, Keskin and Grózer bow brands come to forefront. This result may have come to exist because of the characteristics including accessibility, affordable price, after sales services, and successful customer relationships. Additionally, Turkish archers may have higher level of brand loyalty than European archers due to the lack of particularly outstanding bow brands.

In the literature, there have been many studies which show various effective factors that have significant impact on consumers' brand preferences, but this study shed light on traditional archers' brand preferences in a multicultural perspective with a qualitative research. For further research, this study can be further extended to a deeply quantitative investigation of traditional archers' brand preferences.

\section{References}

Bronnenberg, B. J., Mahajan, V., \& Vanhonacker, W. R. (2000). The emergence of market structure in new repeat-purchase categories: The interplay of market share and retailer distribution. Journal of Marketing Research, 37(1), 16-31.

Bruno, H. A., \& Vilcassim, N. J. (2008). Structural demand estimation with varying product availability. Marketing Science, 27(6), 1126-1131.

Chen, L. J., Gupta, A., \& Rom, W. (1994). A study of price and quality in service operations. International Journal of Service Industry Management, 5, 23-34.

Cornish, L. S. (2012). It's good for me: It has added fibre! An exploration of the role of different categories of functional foods in consumer diets. Journal of Consumer Behaviour, 11(4), 292-302.

De Ruyter, K., Bloemer, J., \& Peeters, P. (1997). Merging service quality and service satisfaction. An empirical test of an integrative model. Journal of Economic Psychology, 18(4), 387-406.

Farris, P., Olver, J., \& De Kluyver, C. (1989). The relationship between distribution and market share. Marketing Science, $8(2), 107-128$.

Grayson, C. E, French, M. J., O’Brien, M. (2007). Traditional archery from 6th continents. Columbia, Missouri: University of Missouri Press.

Grönroos, C. (2000). Service management and marketing: A customer relationship management approach (2nd ed.). Chichester: Wiley.

Hauser, J. R., \& Clausing, D. (1993). How Puritan-Bennett used the house of quality. Sloan Management Review, 34(3), 6170.

Harris, H. (2001). Content analysis of secondary data: A study of courage in managerial decision making. Journal of Business Ethics, 34(3-4), 191-208.

Jayachandran, S., Sharma, S., Kaufman, P., \& Raman, P. (2005). The role of relational information processes and technology use in customer relationship management. Journal of Marketing, 69(4), 177-192.

Klopsteg, P. E. (2004) Archery. Encyclopedia Britannica. Retrieved from www.britannica.com/eb/article- 9001641/archery (last accessed 28.08.2018).

Kotler, P., \& Keller, K. L. (2006). Marketing management (12th ed). Upper Saddle River, NJ: Pearson Prentice-Hall.

Krasnikov, A., Jayachandran, S., \& Kumar, V. (2009). The impact of customer relationship management implementation on cost and profit efficiencies: Evidence from the us commercial banking industry. Journal of Marketing, 73(6), 61-76. 
Kwok, S., Uncles, M., \& Huang, Y. (2006). Brand preferences and brand choices among urban Chinese consumers: An investigation of country-of-origin effects. Asia Pacific Journal of Marketing and Logistics, 18(3), 163-172.

Lehmann, D. R. (2004). Metrics for making marketing matter. Journal of Marketing, 68, 73-75.

Morgan, R. M., \& Hunt, S. D. (1994). The commitment-trust theory of relationship marketing. Journal of Marketing, 58(3), 20-38.

Onwuegbuzie, A. J., \& Leech, N. L. (2007). A call for qualitative power analyses. Quality and Quantity, 41(1), $105-121$.

Pancras, J. (2011). The nested consideration model: Investigating dynamic store consideration sets and store competition. European Journal of Operational Research, 214(2), 340-347.

Payne, A. (2000). Relationship marketing: The U.K. perspective. In J. N. Sheth, \& A. Parvatiyar (Eds.), Handbook of relationship marketing (pp. 39-67). Thousand Oaks, C.A: Sage Publications.

Reibstein, D. J., \& Farris, P. W. (1995). Market share and distribution: A generalization, a speculation, and some implications. Marketing Science, 14(3), 190-202.

Rust, R. T., Lemon, K. N., \& Zeithaml, V. A. (2004). Return on marketing: Using customer equity to focus marketing strategy. Journal of Marketing, 68(1), 109-127.

Sim, L. L., \& Koi, S. M. (2002). Singapore's internet shoppers and their impact on traditional shopping patterns. Journal of Retailing and Consumer Services, 9(2), 115-124.

Thomas, J. S., \& Sullivan, U. Y. (2005). Managing marketing communications with multichannel customers. Journal of Marketing, 69(4), 239-251. 